\title{
PERAN DAN FAKTOR YANG BERHUBUNGAN DENGAN PERILAKU GURU DALAM PENDIDIKAN KESEHATAN REPRODUKSI REMAJA SEKOLAH MENENGAH PERTAMA DI KABUPATEN SUBANG TAHUN 2019
}

\section{The Role and Behavior Related Factors of Teachers in Adolescent Reproductive Health Education of Junior High School Adolescents in Subang District 2019}

\author{
Juariah $^{1}$, Joko Irianto ${ }^{2 *}$ \\ ${ }^{1}$ Badan Penelitian dan Pengembangan Daerah Provinsi Jawa Barat \\ ${ }^{2}$ Pusat Penelitian dan Pengembangan Upaya Kesehatan Masyarakat, \\ Badan Penelitian dan Pengembangan Kesehatan, Kementerian Kesehatan RI \\ E-mail: ai_arriandhi@yahoo.co.id
}

Naskah masuk 13 April 2020; review 27 Mei 2020; disetujui terbit 26 Juni 2020

\begin{abstract}
Background: Teachers have an important role in providing reproductive health education for adolescents. Objective: To analyze the relationship of characteristics, training, knowledge, attitude, identities and school supports with teacher behavior in providing adolescent reproductive health education.

Method: This study was an analytical research with cross-sectional design. The number of sampel were 71 schools that was determined by systematic random sampling. The number of respondents were 421 teachers. The independent variables were characteristics, training, knowledge, attitudes, identities and school supports. The dependent variable was teachers behavior in providing reproductive health education. Data were collected through interviews. The data were analyzed using Chi Square Test and multiple logistic regression.

Result: Factors related to teacher behavior in providing adolescent reproductive health education were gender (OR: 1.64; 95\% CI: 1.105-2.437), employment status (OR: 1.55 ; 95\% CI: 1.03-2.34 ), training participation (OR:1.78; 95\% CI: 1.210-2.623), knowledge (p: 0.000), attitude (OR: 5,81; 95\% CI: 4.412-7.650), facilities (OR: 1749.52 ; 95\% CI: 457.670-6688.005) and implementation (OR: 2008.95; 95\% CI: 512.397-7876.487). The most dominant factors related to the teachers' behavior in providing reproductive health education were facilities (OR: 110.49; 95\% CI: 22.21-549.52) and implementation (OR: 139.28; 95\% CI: 28.56- 679.30).

Conclusion: Adequate support of learning facilites and aspects of implementation had major contribution to the behavior of teachers in providing reproductive health education.
\end{abstract}

Keywords: teacher behavior, education, adolescent reproductive health

\begin{abstract}
Abstrak
Latar belakang: Guru memiliki peranan penting dalam memberikan pendidikan kesehatan reproduksi pada remaja.

Tujuan: Menganalisis hubungan karakteristik, pelatihan, pengetahuan, sikap, identitas dan dukungan sekolah dengan perilaku guru dalam memberikan pendidikan keehatan reproduksi remaja.

Metode: Jenis penelitian ini adalah analitik dengan desain potong lintang. Sampel ditetapkan dengan systematic random sampling berjumlah 71 sekolah. Responden berjumlah 421 orang guru. Variabel independen adalah karakteristik, pelatihan, pengetahuan, sikap, identitas dan dukungan sekolah. Variabel dependen adalah perilaku guru dalam memberikan pendidikan kesehatan reproduksi. Data dikumpulkan melalui wawancara. Data dianalisis dengan uji Chi-square dan regresi logistik ganda.

Hasil: Faktor-faktor yang berhubungan dengan perilaku guru dalam memberikan pendidikan kesehatan reproduksi remaja adalah jenis kelamin (OR:1,64; 95\% CI: 1,105-2,437), status kepegawaian (OR: 1,55 ; $95 \%$ CI: 1,03-2,34 ), keikutsertaan pelatihan (OR:1,78; 95\% CI: 1,210-2,623), pengetahuan (p: 0,000), sikap (OR: 5,81 ; 95\% CI: 4,412-7,650), sarana (OR: 1749,52 ; 95\% CI: 457,670-6688,005) dan pelaksanaan (OR: 2008,95; 95\% CI: 512,397-7876,487). Faktor yang paling dominan berhubungan dengan perilaku guru dalam memberikan pendidikan kesehatan reproduksi adalah sarana (OR: 110,49; 95\% CI: 22,21-549,52) dan pelaksanaan (OR: 139,28; 95\% CI: 28,56- 679,30).
\end{abstract}

Kesimpulan: Dukungan sarana pembelajaran yang memadai dan aspek pelaksanaan memiliki kontribusi utama terhadap perilaku guru dalam memberikan pendidikan kesehatan reproduksi.

Kata kunci: perilaku guru, pendidikan, kesehatan reproduksi remaja 


\section{PENDAHULUAN}

Masa remaja merupakan masa transisi dalam kehidupan seseorang. Masa ini (kelompok usia 10 sampai 19 tahun) merupakan dekade kedua dalam kehidupan, yang mana terjadi perubahan fisik dan psikologis yang sangat besar. ${ }^{1}$ Remaja juga menghadapi berbagai tantangan sosial dan kesehatan. Inisiasi awal aktifitas seksual dan kurangnya pengetahuan dan keterampilan yang memadai untuk menghindari perilaku berisiko, menempatkan remaja pada risiko lebih tinggi mengalami kehamilan yang tidak diinginkan, aborsi yang tidak aman dan infeksi menular seksual termasuk Human Immunodeficiency Virus (HIV)/Acquired Immunodeficiency syndrome (AIDS). ${ }^{1}$ Perilaku berisiko lain pada remaja adalah merokok serta penyalahgunaan Narkotika, Psikotropika dan Zat Adiktif Lainnya (NAPZA).

Pendidikan mengenai kesehatan reproduksi sebaiknya menjadi bagian dari pendidikan yang didapatkan remaja di sekolah. ${ }^{2}$ Hal ini mengingat sebagian besar remaja berada pada kelompok usia sekolah dan menghabiskan banyak waktunya di sekolah. Tentu hal ini bukan berarti mengabaikan remaja lain yang berada di luar sekolah, tetapi dengan adanya wajib sekolah 9 tahun, maka pada kelompok remaja awal dan menengah sebagian besar akan bersekolah. Hal ini ditegaskan oleh penelitian sebelumnya bahwa salah satu faktor sosial yang mempengaruhi kesehatan reproduksi remaja adalah dukungan dan kesempatan yang diberikan oleh institusi kepada remaja ${ }^{3}$, termasuk salah satu yang sangat penting adalah sekolah. Hasil Survei Demografi dan Kesehatan Indonesia (SDKI) 2012 menunjukkan bahwa sekolah merupakan sumber informasi kesehatan reproduksi untuk remaja ${ }^{4}$. Selain itu, hasil penelitian McKay menunjukkan bahwa program pendidikan kesehatan seksual berbasis sekolah yang dikembangkan dan diimplementasikan dengan baik dapat secara efektif membantu remaja mengurangi risiko tertular IMS/HIV dan kehamilan yang tidak diinginkan. ${ }^{5}$ Penelitian lain bahkan menegaskan bahwa pendidikan sekolah digambarkan sebagai vaksin sosial dan dapat berfungsi sebagai alat pencegahan yang kuat. ${ }^{6}$

Guru memiliki peranan penting dalam memberikan informasi dan pendidikan kesehatan reproduksi bagi remaja. Setelah orangtua, guru adalah orang kedua yang menghabiskan sebagian besar waktu dan memiliki kesempatan maksimum untuk berkomunikasi dan mendidik remaja dalam aspek kehidupan yang penting ini. ${ }^{6}$ Menurut penelitian Acharya dkk, remaja, terutama kelompok remaja awal menghabiskan banyak waktunya di sekolah dan mengidolakan gurunya sebagai panutan. ${ }^{7}$ Oleh karena itu guru dapat menjadi konselor terbaik untuk berbagai perubahan fisik dan mental yang terjadi selama periode usia ini. Hasil-hasil kajian lain juga menemukan bahwa guru merupakan sumber informasi utama tentang kesehatan reproduksi setelah teman. ${ }^{8-11}$

Meskipun potensi guru sebagai sumber informasi kesehatan reproduksi untuk remaja besar, tetapi perannya belum optimal. Hal ini seperti yang ditunjukkan dalam hasil penelitian di Bangladesh yang menemukan bahwa siswa dan guru merasa tidak nyaman dengan pembelajaran mengenai isu kesehatan reproduksi di dalam kelas. ${ }^{12}$ Hasil penelitian lain yang dilakukan pada guru SMA di Kota Semarang menunjukkan bahwa meskipun guru memiliki persepsi yang baik tentang pendidikan kesehatan reproduksi, tetapi guru masih sungkan dan tabu saat mengajar pendidikan hubungan seks. ${ }^{13}$

Kabupaten Subang merupakan salah satu kabupaten di Jawa Barat bagian utara yang memiliki karakteristik wilayah yang terbagi atas wilayah pegunungan, dataran rendah, perkotaan dan pantai. Kabupaten ini termasuk daerah risiko tinggi masalah kesehatan reproduksi. Data tahun 2018 menunjukkan bahwa kabupaten ini menduduki peringkat ke4 kasus baru HIV/AIDS di Jawa Barat. ${ }^{14}$

\footnotetext{
*Korespondensi: ai_arriandhi@yahoo.co.id

(C) Badan Penelitian dan Pengembangan Kesehatan ISSN: 2354-8762 (elektronik); ISSN: 2087-703X (cetak)
} 
Selain itu, menurut Badan Nasional Penempatan dan Perlindungan Tenaga Kerja Indonesia (BNP2TKI), kabupaten ini juga merupakan salah satu penyumbang tenaga migran terbanyak di Jawa Barat. ${ }^{15}$ Banyaknya orangtua yang menjadi pekerja migran ini, menjadikan lemahnya pengawasan dan bimbingan terhadap remaja, sehingga mereka dapat terjerumus ke dalam perilaku berisiko. Budaya menikah di usia dini yang masih tinggi di satu sisi serta pengaruh negatif media dan lingkungan yang mendukung remaja melakukan pergaulan bebas di sisi lain, meningkatkan risiko kehamilan pada remaja di daerah ini.

Mengingat pentingnya peran sekolah dalam memberikan dukungan kepada remaja dalam memilih perilaku hidup sehat dan dominasi peran guru sebagai sumber informasi kesehatan reproduksi bagi murid bersekolah, maka penelitian ini bertujuan untuk menganalisis hubungan antara karakteristik (usia, jenis kelamin, agama, tempat tinggal, pendidikan, status kepegawaian, status guru, lama bekerja sebagai guru, lama menjabat dan lama mengampu pelajaran yang mengandung topik kesehatan reproduksi), pelatihan, pengetahuan, sikap, identitas dan dukungan sekolah dengan perilaku guru dalam memberikan pendidikan kesehatan reproduksi remaja.

\section{METODE}

Jenis penelitian ini adalah penelitian analitik dengan desain potong lintang yang dilaksanakan di Sekolah Menengah Pertama (SMP) terpilih di Kabupaten Subang. Populasi dibagi berdasarkan karakteristik lokasi yaitu SMP yang berlokasi di daerah pegunungan, SMP yang berlokasi di daerah perkotaan, SMP yang berlokasi di dataran rendah dan SMP yang berlokasi di daerah pantai. Penelitian dilakukan pada bulan Januari sampai Desember 2019. Populasi penelitian ini adalah semua sekolah menengah tingkat pertama di Kabupaten Subang Jawa Barat milik pemerintah maupun swasta termasuk Sekolah Menengah Pertama (SMP), Madrasah Tsanawiyah (MTS) dan Sekolah Luar Biasa (SLB), dengan jumlah sekolah seluruhnya sebanyak 247 sekolah. ${ }^{16}$ Sedangkan yang menjadi sampel penelitian adalah SMP terpilih di Kabupaten Subang sebanyak 71 sekolah. Sampel ditetapkan dengan sistematik random sampling. Teknik pengambilan sampel ini dipilih dengan pertimbangan lebih mudah dilakukan di lapangan dan kemungkinan lebih kecil melakukan kesalahan pemilihan sampel serta sampel lebih terdistribusi dengan baik. ${ }^{17}$ Tahapan pemilihan sampel adalah sebagai berikut: pertama, membagi kecamatan sesuai dengan karakteristik geografis lokasi yaitu: SMP yang berlokasi di kecamatan daerah pegunungan, SMP yang berlokasi di kecamatan daerah perkotaan, SMP yang berlokasi di kecamatan dataran rendah dan SMP yang berlokasi di daerah utara/pantai utara. Selanjutnya daftar sekolah diurutkan sesuai dengan karakteritik wilayah dan dibagi sesuai dengan status sekolah yaitu negeri, swasta dan SLB kemudian diberi nomor urut untuk memudahkan dalam melakukan randomisasi. Setelah penetapan wilayah sesuai karakteristik geografis, selanjutnya dilakukan pembagian proporsi jumlah sampel sesuai dengan populasi sekolah di setiap wilayah. Proporsi sampel didapatkan dengan rumus sebagai berikut:

$$
\begin{aligned}
& \mathrm{n}_{\mathrm{x}}=\left(\mathrm{N}_{\mathrm{x}} / \mathrm{N}\right) \times \mathrm{n} \\
& \mathrm{n}_{\mathrm{x}}=\text { Sampel proporsi } \\
& \mathrm{N}_{\mathrm{x}}=\text { Populasi proporsi } \\
& \mathrm{N}=\text { Populasi penelitian } \\
& \mathrm{n}=\text { Sampel penelitian }
\end{aligned}
$$

Proporsi sekolah yang menjadi sampel penelitian adalah 20 sekolah di daerah pegunungan, 12 sekolah di daerah perkotaan, 25 sekolah di daerah dataran rendah dan 14 sekolah di daerah pantai. Mengenai jumlah sekolah yang menjadi sampel penelitian berdasarkan wilayah dan status sekolah dapat dilihat pada Tabel 1. Setelah sampel untuk setiap kelompok populasi diketahui, selanjutnya adalah menentukan $k$ untuk setiap kelompok sampel.

$$
k=\mathrm{N}_{\mathrm{x}} / \mathrm{n}_{\mathrm{x}}
$$

sehingga $k$ untuk setiap kelompok populasi dapat berbeda karena ada proporsi. Apabila $k$ mengandung nilai desimal, maka digenapkan ke bawah. Setelah diketahui $k$ untuk setiap kelompok populasi, maka selanjutnya dirandomisasi nomor urut sekolah $\leq k$. Cara melakukan randomisasi nomor urut sekolah yang pertama menjadi sampel adalah dengan cara mengundi nomor yang sama atau lebih kecil dari nilai $k$, nomor yang keluar adalah 
yang menjadi nomor urut sekolah yang pertama dipilih sebagai sampel, selanjutnya sampel sekolah dipilih dengan menambahkan $k$ pada nomor urut sekolah yang terpilih sebelumnya.
Setelah terpilih sekolah yang menjadi sampel, maka ditetapkan responden penelitian dengan kriteria inklusi antara lain guru yang menjabat

\section{Tabel 1. Jumlah Sekolah yang Menjadi Sampel Penelitian Berdasarkan Wilayah dan Status Sekolah}

\begin{tabular}{llcccccccc}
\hline & & \multicolumn{9}{c}{ Status sekolah } & \multirow{2}{*}{ Jumlah } \\
\cline { 3 - 8 } No & \multirow{2}{*}{ Wilayah } & \multicolumn{2}{c}{ Negeri } & \multicolumn{2}{c}{ Swasta } & \multicolumn{2}{c}{ SLB } & \\
\cline { 2 - 8 } & & $\mathbf{N x}$ & $\mathbf{n x}$ & $\mathbf{N x}$ & $\mathbf{n x}$ & $\mathbf{N x}$ & $\mathbf{n x}$ & $\mathbf{N x}$ & $\mathbf{N x}$ \\
\hline 1. & Pegunungan & 15 & 4 & 56 & 16 & 2 & 0 & 73 & 20 \\
2. & Perkotaan & 13 & 4 & 24 & 7 & 4 & 1 & 41 & 12 \\
3. & Dataran rendah & 33 & 10 & 47 & 14 & 3 & 1 & 83 & 25 \\
4. & Pantai Utara & 22 & 6 & 27 & 8 & 1 & 0 & 50 & 14 \\
\hline & Jumlah & 83 & 24 & 154 & 45 & 10 & 2 & 247 & 71 \\
\hline
\end{tabular}

sebagai kepala sekolah, wakil kepala sekolah bidang kesiswaan, wakil kepala sekolah bidang kurikulum, guru mata pelajaran yang mengandung topik kesehatan reproduksi remaja yaitu mata pelajaran agama, Ilmu Pengetahuan Alam (IPA) serta pendidikan jasmani, olahraga dan kesehatan dan bersedia menjadi responden yang dibuktikan dengan informed consent. Sedangkan kriteria eksklusi adalah guru yang tidak menjabat/mengajar pada salah satu mata pelajaran terpilih, yang tidak bersedia menjadi responden penelitian dan guru yang memenuhi kriteria tetapi pada saat kegiatan penelitian sedang sakit atau cuti. Responden penelitian ini berjumlah 421 orang yang terdiri dari 70 kepala sekolah, 70 wakil kepala sekolah bidang kurikulum, 71 wakil kepala sekolah bidang kesiswaan, guru mata pelajaran IPA, pendidikan jasmani olahraga dan kesehatan serta guru pendidikan agama masingmasing 70 orang.

Mengacu kepada Preceed-Proceed model yang dikembangkan oleh Green \& Kreuter ${ }^{18}$ maka variabel terikat dalam penelitian ini adalah perilaku guru dalam memberikan pendidikan kesehatan reproduksi remaja sedangkan variabel bebas terdiri atas faktor predisposisi (predisposing factor) yaitu karakteristik (usia, jenis kelamin, agama, tempat tinggal, pendidikan, status kepegawaian, status guru, lama bekerja sebagai guru, lama menjabat dan lama mengajar pada mata pelajaran yang mengandung topik kesehatan reproduksi), pengetahuan mengenai kesehatan reproduksi remaja dan sikap terhadap pendidikan kesehatan reproduksi remaja; faktor pendukung (enabling factor) yaitu pelatihan kesehatan reproduksi (kepesertaan dan waktu pelatihan) dan dukungan sekolah (kebijakan, sarana dan pelaksanaan) dan faktor pendorong (reinforcing factor) yaitu identitas sekolah (lokasi dan status sekolah).

Sebelum pengumpulan data, dilakukan uji coba instrumen penelitian. Uji coba dilaksanakan di dua sekolah yaitu satu sekolah negeri dan satu sekolah swasta yang berlokasi di Kabupaten Subang. Sekolah untuk uji coba ini tidak dipilih kembali sebagai lokasi penelitian. Responden yang diwawancarai pada masing-masing sekolah berjumlah enam orang, terdiri dari kepala sekolah, wakil kepala sekolah bidang kurikulum, wakil kepala sekolah bidang kesiswaan, guru mata pelajaran agama, guru mata pelajaran IPA dan guru mata pelajaran pendidikan jasmani, olahraga dan kesehatan. Hasil uji validitas dengan korelasi product moment dari Pearson dengan tingkat signifikasi 0,05 menunjukkan hasil bahwa nilai $\mathrm{r}$ hitung lebih besar dari nilai $r$ tabel $(>0,5760)$ yang berarti instrumen yang digunakan valid, dapat memberikan hasil ukur yang tepat dan akurat sesuai dengan tujuan penggunaan instrumen. 
Sedangkan uji reliablitas dengan Cronbach Alpha menunjukkan nilai sebesar $0,731(>0,60)$ yang berarti instrumen yang digunakan cukup reliabel.

Pengumpulan data dilakukan dengan cara wawancara menggunakan panduan kuesioner. Pengolahan data dilakukan melalui beberapa tahapan, yaitu editing, koding, entri data dan pembersihan data. Data yang sudah diolah kemudian dianalisis dengan bantuan SPSS versi 25 . Analisis bivariat dilakukan dengan uji Chi-square dengan nilai $\mathrm{p}$ lebih kecil dari 0,05 yang diasumsikan terdapat hubungan yang signifikan. Sedangkan analisis multivariat dilakukan dengan uji regresi logistik ganda. Adapun variabel yang diikutsertakan dalam analisis multivariat dipilih melalui analisis bivariat yang memenuhi syarat dengan nilai signifikansi p lebih kecil dari 0,25.

Sebelum melaksanakan penelitian maka dilakukan pengurusan ijin penelitian ke sekolah yang terpilih sebagai lokasi penelitian melalui: Dinas Pendidikan Kabupaten Subang untuk SMP Negeri dan sebagian SMP swasta; Perwakilan Kementerian Agama Kabupaten Subang untuk MTs negeri dan swasta; dan Dinas Pendidikan Provinsi Jawa Barat untuk SLB. Penelitian ini juga sudah mendapatkan persetujuan etik (Ethical Approval) dari Komisi Etik Penelitian Kesehatan, Badan Penelitian dan Pengembangan Kesehatan, Kementerian Kesehatan RI nomor LB.02.01/2/KE.296/2019.

\section{HASIL}

Hasil penelitian pada Tabel 2 menunjukkan bahwa karakteristik usia responden 20,2 persen berada pada kelompok usia 35-39 tahun. Sedangkan jenis kelamin responden 61,5 persen adalah laki-laki. Mengenai agama responden, 99,5 persen menganut agama Islam. Lebih dari setengah $(59,9 \%)$ responden bertempat tinggal di daerah satu kecamatan dengan sekolah tempat mereka bekerja. Sebagian besar responden (80,5\%) menyelesaikan pendidikan tertinggi sarjana. Sedangkan untuk status kepegawaian responden 66,5 persen memiliki status kepegawaian non PNS (bukan Pegawai Negeri Sipil). Mengenai status guru, masih ada 27,3 persen yang berstatus kontrak dan 8,1 persen yang bertatus guru tidak tetap. Mengenai masa kerja sebagai guru, dari 210 responden guru mata pelajaran, 38,1 persen responden memiliki masa kerja sebagai guru kurang dari 5 tahun, dari jumlah tersebut, 49 persen responden sudah mengajar selama lebih dari 5 tahun pada mata pelajaran yang diampunya saat penelitian dilakukan. Sedangkan mengenai lama menjabat, untuk responden yang menjabat sebagai kepala sekolah, wakil kepala sekolah bidang kesiswaan dan wakil kepala sekolah bidang kurikulum, dari 211 responden, 53,6 persen menjabat di sekolah lokasi penelitian kurang dari 5 tahun.

Tabel 2. Hubungan Karakteristik dengan Perilaku

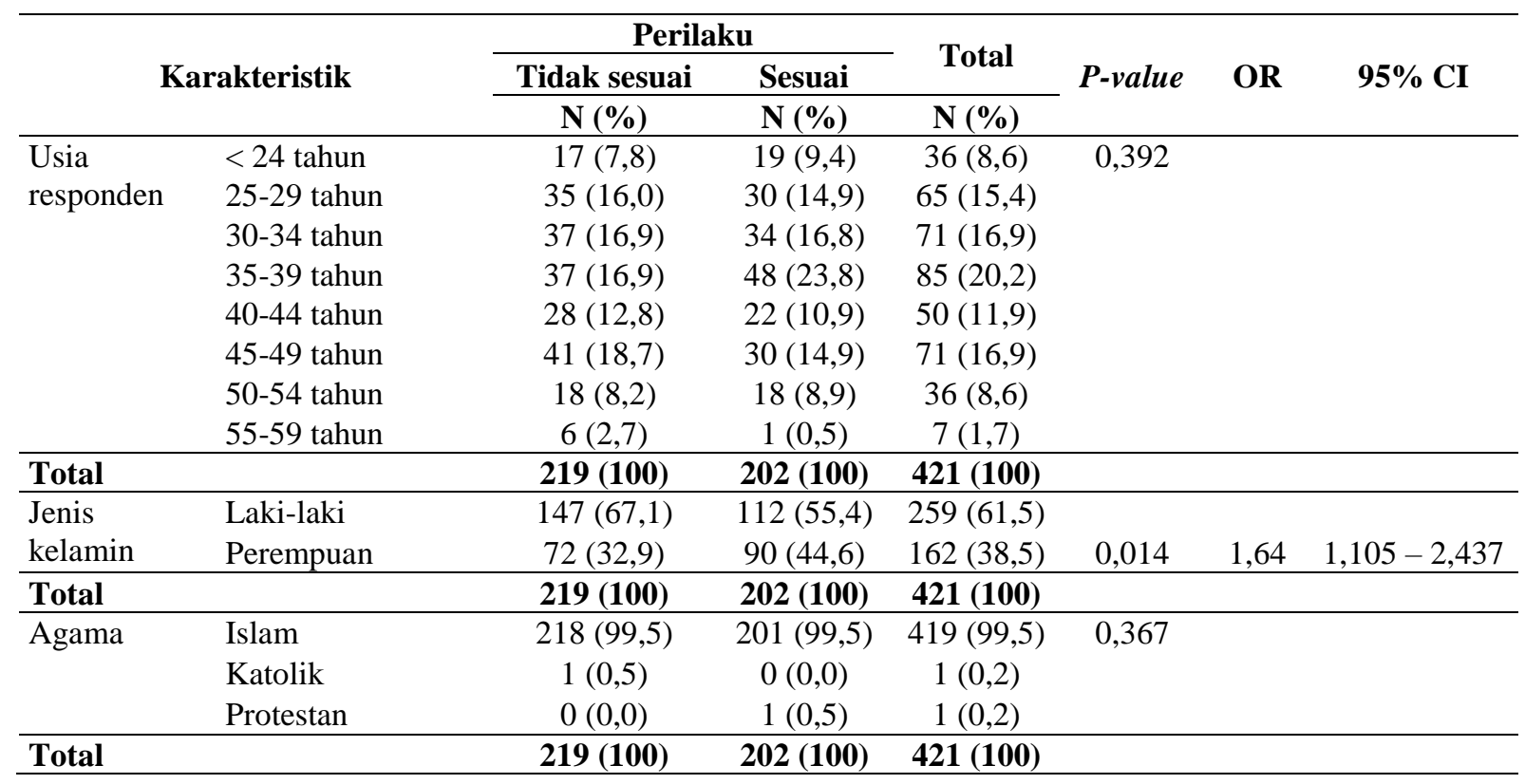


(Lanjutan Tabel 2.)

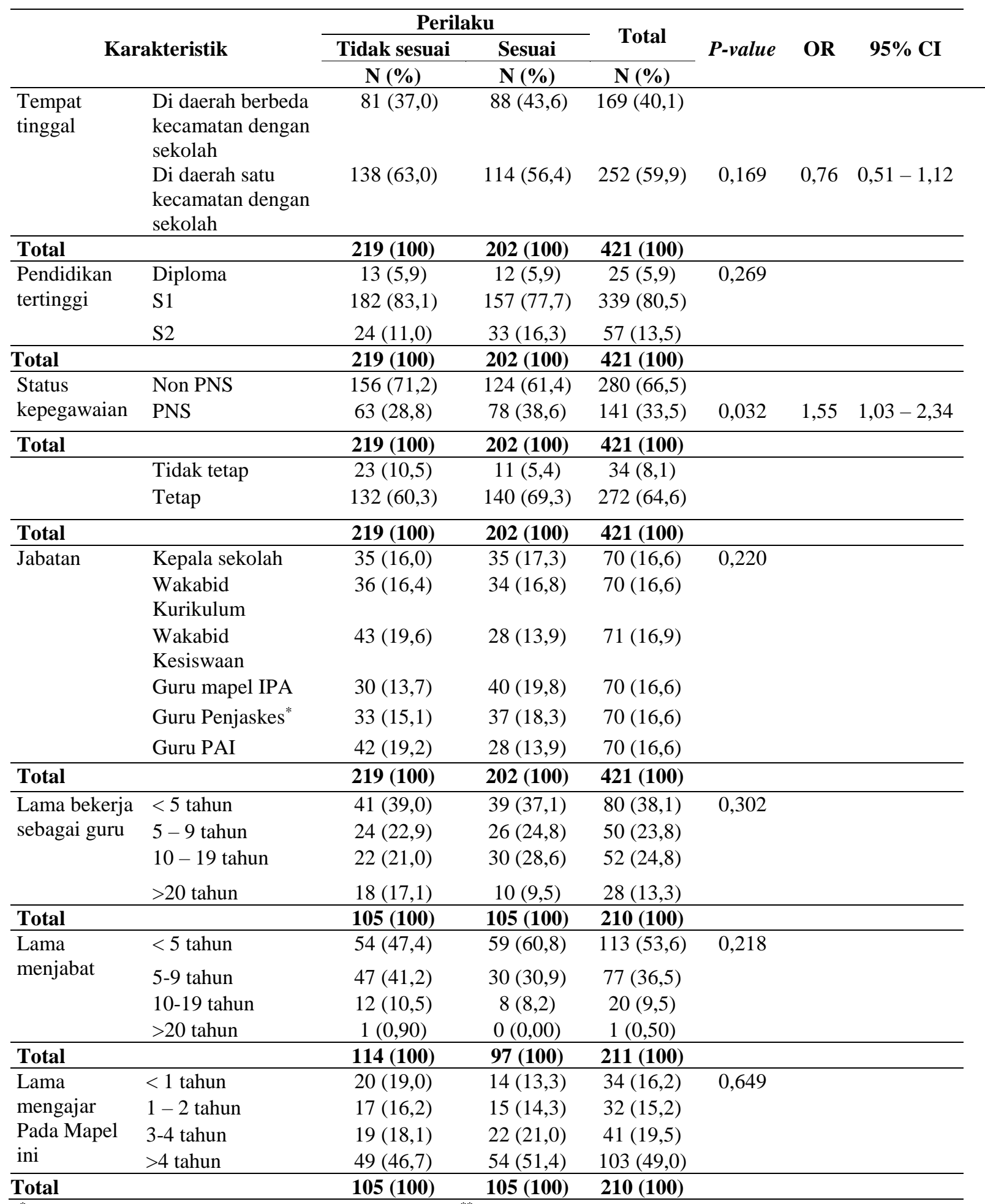

*Penjaskes: Pendidikan jasmani, olahraga dan kesehatan, ${ }^{* *}$ PAI: Pendidikan agama Islam

Tabel 2 menunjukkan bahwa beberapa subvariabel karakteritistik yaitu usia, agama, tempat tinggal, pendidikan tertinggi, status guru, jabatan, lama bekerja sebagai guru, lama menjabat dan lama mengajar pada mata pelajaran yang mengandung topik kesehatan reproduksi (IPA, pendidikan jasmani, olahraga dan kesehatan dan pendidikan agama) tidak berhubungan dengan perilaku responden dalam pendidikan kesehatan reproduksi remaja (masing-masing nilai $\mathrm{p}$ berturut-turut 0,392 ; 0,$367 ; 0,169 ; 0,269 ; 0,072 ; 0,220 ; 0,302 ; 0,218$; $0,649)$. Sedangkan sub variabel jenis kelamin (nilai p: 0,014 dan nilai CI: $1,105-2,437$ ) dan 
status kepegawaian (nilai p: 0,032 dan CI: 1,037-2,341) memiliki hubungan dengan perilaku responden dalam pendidikan kesehatan reproduksi remaja.

Pada Tabel 3 diketahui bahwa 52,5 persen responden tidak pernah ikut serta dalam pelatihan kesehatan reproduksi remaja. Sedangkan untuk waktu mengikuti pelatihan kesehatan reproduksi remaja dari 200 responden yang pernah mengikuti pelatihan kesehatan reproduksi remaja, 53,5 persen mendapatkannya setelah bekerja (in-service). Pada penelitian ini subvariabel keikutsertaan pelatihan memiliki hubungan dengan perilaku responden dalam pendidikan kesehatan reproduksi (nilai p: 0,003 dan CI: 1,210-2,623). Sedangkan waktu mengikuti pelatihan tidak berhubungan dengan perilaku dalam pendidikan kesehatan reproduksi remaja (nilai p: 0,334).

Tabel 3. Hubungan Pelatihan Kesehatan Reproduksi Remaja dengan Perilaku

\begin{tabular}{|c|c|c|c|c|c|c|c|}
\hline \multirow{2}{*}{\multicolumn{2}{|c|}{$\begin{array}{c}\text { Pelatihan kesehatan } \\
\text { reproduksi remaja }\end{array}$}} & \multicolumn{2}{|c|}{ Perilaku } & \multirow[b]{2}{*}{ Total } & \multirow[b]{2}{*}{ P-value } & \multirow[b]{2}{*}{ OR } & \multirow[b]{2}{*}{$95 \% \mathrm{CI}$} \\
\hline & & $\begin{array}{c}\text { Tidak } \\
\text { sesuai } \\
\mathbf{N}(\%)\end{array}$ & $\frac{\text { Sesuai }}{\mathrm{N}(\%)}$ & & & & \\
\hline Keikutsertaan & Tidak pernah & $130(594)$ & $91(450)$ & $221(525)$ & & & \\
\hline Pelatihan & Pernah & $89(40,6)$ & $111(55,0)$ & $200(47,5)$ & 0,003 & 1,78 & $1,210-2,623$ \\
\hline Total & & $219(100)$ & $202(100)$ & $421(100)$ & & & \\
\hline Waktu & Pre-service & $38(42,7)$ & $55(49,5)$ & $93(46,5)$ & & & \\
\hline Pelatihan & In-service & $51(57,3)$ & $56(50,5)$ & $107(53,5)$ & 0,334 & 0,759 & $0,433-1,330$ \\
\hline Total & & 89 (100) & 111(100) & $200(100)$ & & & \\
\hline
\end{tabular}

Hubungan pengetahuan dengan perilaku dapat dilihat pada Tabel 4 yang menunjukkan 23,5 persen responden yang memiliki pengetahuan baik, dengan nilai p 0,000. Sedangkan Tabel 5 menunjukkan bahwa 58 persen responden memiliki sikap yang mendukung terhadap pendidikan kesehatan reproduksi remaja, hubungan tersebut signifikan dengan perilaku (nilai p: 0,000 dan CI: 4,412-7,650).

Tabel 4. Hubungan Pengetahuan dengan Perilaku

\begin{tabular}{|c|c|c|c|c|c|}
\hline \multirow{3}{*}{ Pengetahuan } & \multicolumn{3}{|c|}{ Perilaku } & \multirow{3}{*}{ P-value } & \multirow{3}{*}{$95 \% \mathrm{CI}$} \\
\hline & Tidak sesuai & Sesuai & Total & & \\
\hline & $\mathbf{N}(\%)$ & $\mathbf{N}(\%)$ & $\mathbf{N}(\%)$ & & \\
\hline Kurang & $116(53,0)$ & $6(3,0)$ & $122(29,0)$ & 0,000 & \\
\hline Cukup & $94(42,9)$ & $106(52,5)$ & $200(47,5)$ & & \\
\hline Baik & $9(4,1)$ & $90(44,6)$ & $99(23,5)$ & & \\
\hline Total & $219(100)$ & $202(100)$ & $421(100)$ & & \\
\hline
\end{tabular}

Tabel 5. Hubungan Sikap dengan Perilaku

\begin{tabular}{|c|c|c|c|c|c|c|}
\hline \multirow{3}{*}{ Sikap } & \multicolumn{3}{|c|}{ Perilaku } & \multirow{3}{*}{ P-value } & \multirow{3}{*}{ OR } & \multirow{3}{*}{$95 \% \mathrm{CI}$} \\
\hline & Tidak sesuai & Sesuai & Total & & & \\
\hline & $\mathrm{N}(\% 0$ & $\mathbf{N}(\%)$ & $\mathbf{N}(\%)$ & & & \\
\hline Tidak mendukung & $177(80,8)$ & $0(0,0)$ & $177(42,0)$ & & & \\
\hline Mendukung & $42(19,2)$ & $202(100)$ & $244(58,0)$ & 0,000 & 5,81 & $4,412-7,650$ \\
\hline Total & $219(100)$ & $202(100)$ & $421(100)$ & & & \\
\hline
\end{tabular}


Mengenai hubungan identitas sekolah dengan perilaku responden dapat dilihat pada Tabel 6 yang menunjukkan bahwa 35,4 persen responden yang bekerja di daerah dataran, 64,6 persen bekerja di sekolah berstatus swasta. Hasil analisis menunjukkan bahwa subvariabel identitas sekolah yaitu lokasi dan status sekolah tidak memiliki hubungan yang signifikan dengan perilaku responden dalam memberikan pendidikan kesehatan reproduksi remaja (nilai p: 0,778 dan 0,126).

Tabel 6. Hubungan Identitas Sekolah dengan Perilaku

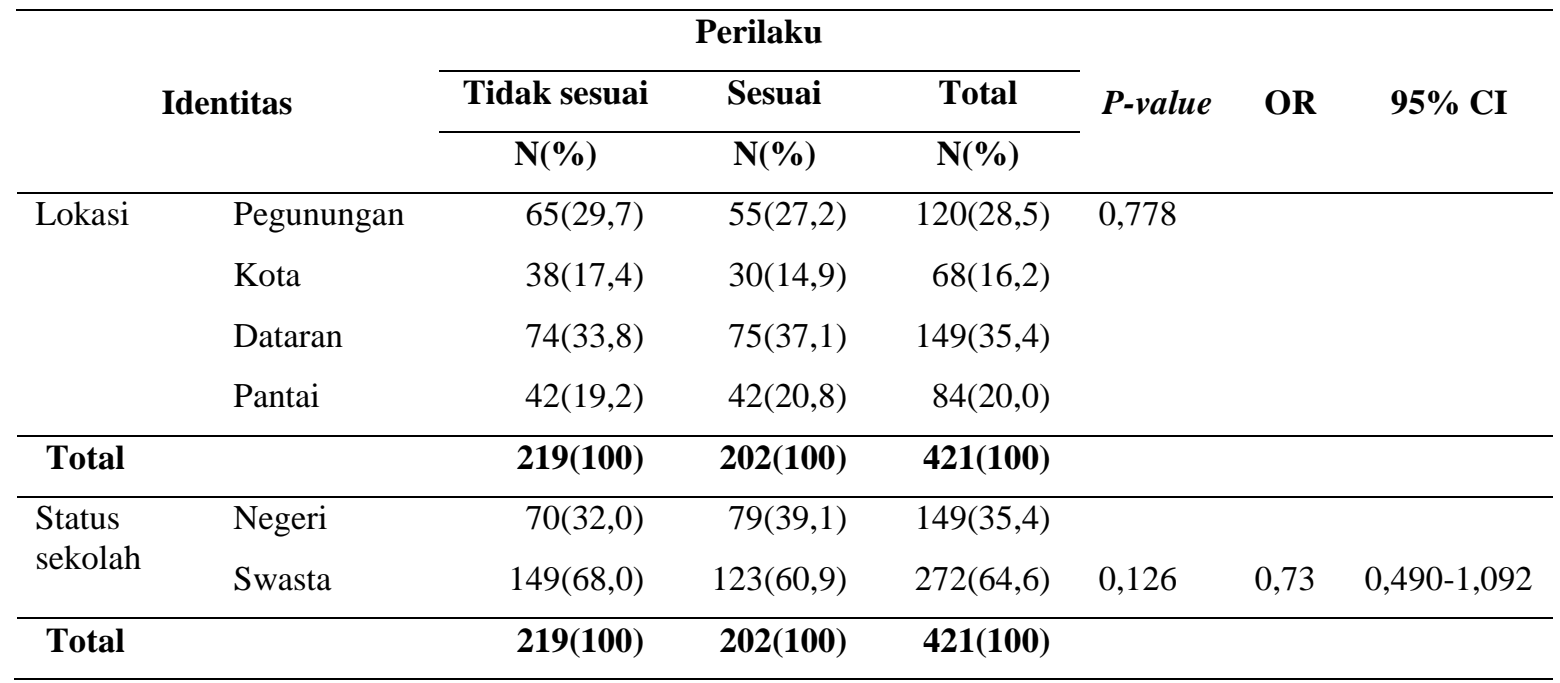

Tabel 7 menunjukkan hasil analisis hubungan variabel dukungan dengan perilaku. Pada tabel ini dapat dilihat bahwa untuk subvariabel kebijakan, 88,8 persen responden bekerja di sekolah yang memiliki kebijakan tidak mendukung terhadap kesehatan reproduksi remaja, 50,8 persen memiliki sarana yang tidak mendukung terhadap pendidikan kesehatan reproduksi. Adapun untuk aspek pelaksanaan, 51,1 persen responden tidak sesuai dalam pelaksanaan pendidikan kesehatan reproduksi. Analisis selanjutnya menunjukan bahwa kebijakan tidak memiliki hubungan yang signifikan dengan perilaku. Sedangkan subvariabel sarana dan pelaksanaan memiliki hubungan yang signifikan dengan perilaku (sarana dengan nilai p: 0,000 dan CI: 457,6706688,005; sedangkan pelaksanaan dengan nilai p: 0,000 dan CI: 512,397-7876,487).

Tabel 7. Hubungan Dukungan Sekolah dengan Perilaku

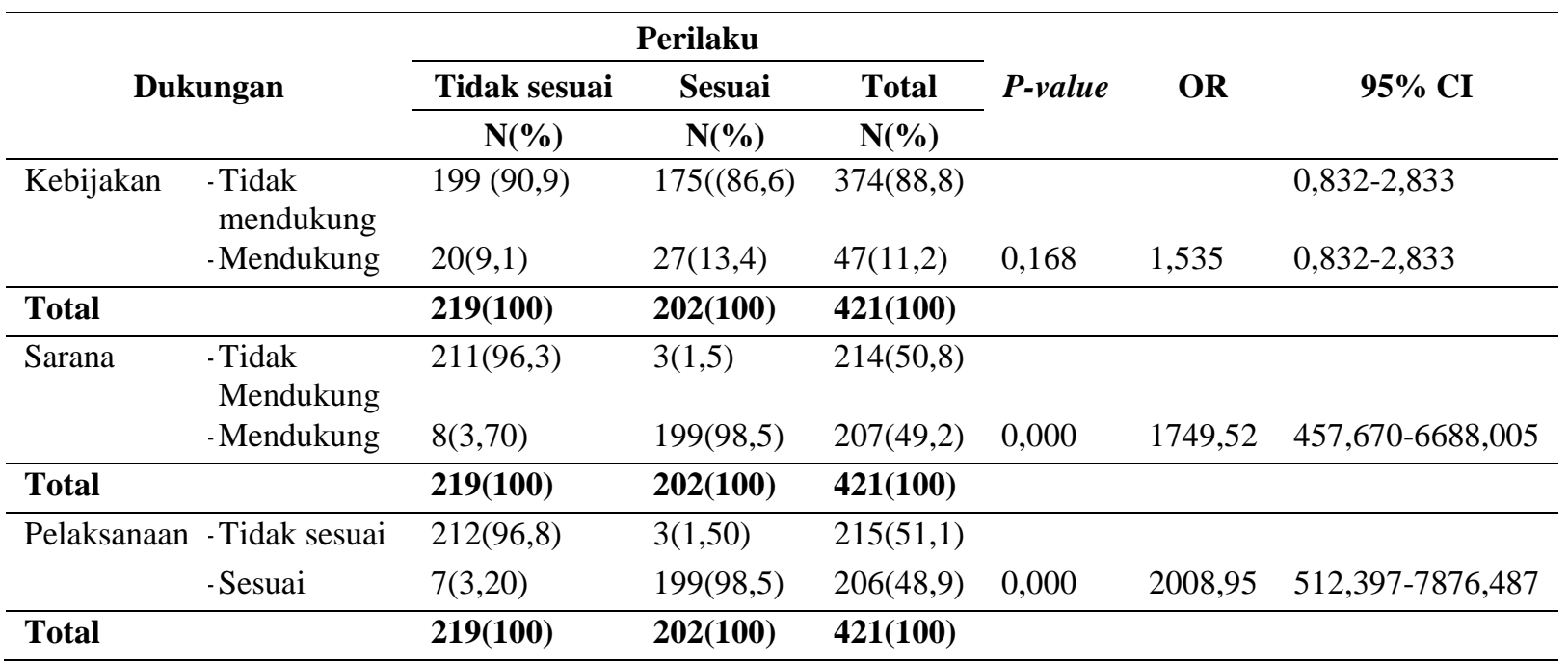


Tabel 8. Faktor-faktor Determinan Perilaku

\begin{tabular}{lccc}
\hline \multicolumn{1}{c}{ Subvariabel } & $\boldsymbol{P}$-value & OR & 95\% CI \\
\hline Sarana & 0,000 & 110,49 & $22,21-549,52$ \\
Pelaksanaan & 0,000 & 139,28 & $28,56-679,30$ \\
\hline
\end{tabular}

Hasil akhir analisis multivariat menunjukkan bahwa subvariabel sarana dan pelaksanaan yang paling signifikan berhubungan dengan perilaku guru dalam pendidikan kesehatan reproduksi remaja dengan nilai p: 0,000 (Tabel 8). Hasil analisis didapatkan nilai Odds Ratio (OR) sarana sebesar 110,5 dan pelaksanaan sebesar 139 yang artinya guru yang memiliki sarana yang mendukung berpeluang untuk memiliki perilaku yang sesuai dalam memberikan pendidikan kesehatan reproduksi sebesar 110,5 kali dibanding dengan guru yang memiliki sarana yang tidak mendukung dan guru yang memiliki pelaksanaan yang sesuai berpeluang untuk memiliki perilaku yang sesuai dalam memberikan pendidikan kesehatan reproduksi sebesar 139 kali lebih tinggi dibanding dengan guru yang memiliki pelaksanaan yang tidak sesuai. Hasil analisis dengan regresi logistik juga menunjukkan nilai overall percentage sebesar 98,1 yang berarti ketepatan model penelitian ini sebesar 98,1 persen. Nilai Nagelkerke $R$ Square sebesar 0,949 dan Cox \& Snell $R$ Square 0,711 yang berarti 94,9 persen fenomena perilaku guru dalam memberikan pendidikan kesehatan reproduksi remaja dipengaruhi oleh dua sub variabel yaitu sarana dan pelaksanaan dan hanya 5,1 persen dipengaruhi oleh faktor lain di luar kedua subvariabel tersebut.

\section{PEMBAHASAN}

Hasil penelitian ini menemukan bahwa variabel/subvariabel yang berhubungan dengan perilaku responden dalam pendidikan kesehatan reproduksi remaja adalah jenis kelamin, status kepegawaian, keikutsertaan pelatihan, pengetahuan, sikap, sarana dan pelaksanaan. Sedangkan variabel/subvariabel usia, agama, tempat tinggal, pendidikan tertinggi, status guru, jabatan, lama bekerja sebagai guru, lama menjabat dan lama mengajar pada mata pelajaran yang mengandung topik kesehatan reproduksi (IPA, pendidikan jasmani, olahraga dan kesehatan, dan pendidikan agama), waktu mengikuti pelatihan, lokasi dan status sekolah serta kebijakan tidak berhubungan dengan perilaku responden dalam pendidikan kesehatan reproduksi remaja. Faktor yang paling signifikan berhubungan dengan perilaku guru dalam pendidikan kesehatan reproduksi remaja adalah sarana dan pelaksanaan.

Perilaku responden dalam memberikan pendidikan kesehatan reproduksi pada penelitian ini terlihat bahwa 52 persen yang tidak sesuai dan 48 persen yang sesuai. Komponen pertanyaan perilaku dalam pendidikan kesehatan reproduksi remaja berbeda antara untuk kepala sekolah/wakil kepala sekolah bidang kurikulum/wakil kepala sekolah bidang kesiswaan dan untuk guru IPA/pendidikan jasmani olahraga dan kesehatan/pendidikan agama. Untuk responden pertama, pertanyaan perilaku mencakup tentang frekuensi evaluasi pembelajaran kesehatan reproduksi dan metode evaluasi sedangkan untuk responden kedua, pertanyaan yang diajukan berkaitan dengan substansi/materi kesehatan reproduksi sesuai dengan kelas yang diampu (kelas VII, VIII atau IX) dan jumlah jam yang digunakan dalam pembelajaran kesehatan reproduksi.

Hasil penelitian ini menunjukkan adanya hubungan yang signifikan antara jenis kelamin responden dengan perilaku dalam pendidikan kesehatan reproduksi remaja (nilai p: 0,014, OR: 1,64, CI: 1,105-2,437). Hal ini berarti bahwa responden guru perempuan berpeluang 1,64 kali lebih tinggi untuk berperilaku yang sesuai dalam pendidikan kesehatan reproduksi remaja dibandingkan dengan guru laki-laki.

Status kepegawaian memiliki hubungan yang signifikan dengan perilaku dalam pendidikan kesehatan reproduksi (nilai p: 0,032, OR: 1,55, CI: 1,037-2,341) yang berarti guru yang memiliki status kepegawaian PNS berpeluang 1,55 kali lebih tinggi untuk berperilaku sesuai dalam memberikan pendidikan kesehatan reproduksi dibandingkan dengan guru yang 
memiliki status kepegawaian non PNS. Hal ini kemungkinan terjadi karena karena guru-guru yang berstatus PNS lebih memiliki peluang kesempatan untuk mendapatkan update informasi materi maupun metode pembelajaran termasuk yang terkait dengan kesehatan reproduksi remaja. Namun hasil penelitian ini berbeda dengan penelitian pada guru-guru SMA Negeri se-Kabupaten Rembang, yang menunjukkan hasil tidak ada perbedaan kinerja antara guru yang berstatus PNS dan non PNS. ${ }^{19}$

Keikutsertaan pelatihan kesehatan reproduksi remaja memiliki hubungan yang signifikan dengan perilaku dalam pendidikan kesehatan reproduksi remaja (nilai p: 0,003 , OR: $1,78, \mathrm{CI}$ : 1,210-2,623). Hal ini berarti responden yang pernah mengikuti pelatihan kesehatan reproduksi remaja memiliki peluang 1,78 kali lebih tinggi untuk berperilaku yang sesuai dalam memberikan pendidikan kesehatan reproduksi remaja dibandingkan dengan yang tidak pernah mengikuti pelatihan kesehatan reproduksi remaja. hal ini sejalan dengan hasil penelitian terdahulu bahwa pelatihan berpengaruh terhadap kompetensi guru. ${ }^{20}$ pelatihan mengenai topik-topik kesehatan reproduksi remaja merupakan upaya untuk meningkatkan kompetensi guru terkait kesehatan reproduksi remaja. pemahaman guru mengenai materi kesehatan reproduksi remaja yang semakin baik dapat meningkatkan kualitas penyampaian materi pada siswa. ${ }^{21}$

Tingkat pengetahuan mengenai kesehatan reproduksi remaja memiliki hubungan yang signifikan dengan perilaku dalam pendidikan kesehatan reproduksi remaja (nilai p: 0,000). hal ini berarti guru yang memiliki pengetahuan yang baik mengenai kesehatan reproduksi remaja lebih berpotensi untuk melakukan pendidikan kesehatan reproduksi yang sesuai. sebaliknya guru yang memiliki pengetahuan yang kurang cenderung berisiko untuk memberikan pendidikan kesehatan reproduksi yang tidak sesuai artinya baik secara substansi materi dan/atau kecukupan jam mengajar yang tidak sesuai. Temuan ini sejalan dengan hasil penelitian lain yang menyebutkan bahwa terdapat hubungan yang signifikan antara tingkat pemahaman guru tentang kompetensi pedagogik dengan tingkat kemampuan mengajar. $^{22} \mathrm{Hal}$ ini diperkuat dengan pernyataan bahwa pengetahuan merupakan determinan terhadap perubahan perilaku seseorang. ${ }^{23}$

Sikap adalah suatu bentuk evaluasi atau reaksi terhadap suatu aspek di lingkungan sekitar dan mendasari seseorang dalam proses pembentukan perilaku. ${ }^{23}$ Sikap merupakan kecenderungan berperilaku. Hasil penelitian ini menunjukkan bahwa sikap memiliki hubungan yang signifikan dengan perilaku dalam pendidikan kesehatan reproduksi remaja (nilai p: 0,000, OR: 5,81, CI: 4,412-7,650). Hal ini berarti responden yang memiliki sikap mendukung memiliki peluang 5,81 kali lebih tinggi untuk melakukan pendidikan kesehatan reproduksi yang sesuai dibandingkan dengan responden yang memiliki sikap tidak mendukung.

Setelah dilakukan analisis secara multivariat ditemukan hasil bahwa faktor-faktor predisposisi (predisposing/motivating factors) yang berpotensi untuk mempengaruhi perilaku, sebagaimana yang dijelaskan dalam model Precede-Proceed yang dikembangkan oleh Green \& Kreuter $^{18}$ pada penelitian ini tidak memiliki hubungan yang signifikan dengan perilaku guru dalam pendidikan kesehatan reproduksi remaja. Hal ini kemungkinan terjadi karena walaupun memiliki pengetahuan dan sikap yang baik mengenai kesehatan reproduksi remaja, tetapi apabila sarana dan pelaksanaan (enabling factors) tidak mendukung, maka pendidikan kesehatan reproduksi tidak dapat dilakukan dengan baik.

Sub variabel dukungan terdiri atas kebijakan, sarana dan pelaksanaan. Pada penelitian ini kebijakan tidak memiliki hubungan yang signifikan dengan perilaku dalam pendidikan kesehatan reproduksi remaja (nilai $p=0,168$ ). Temuan ini berbeda dengan model yang dikemukakan oleh Green \& Kreuter (2005) ${ }^{18}$ bahwa kebijakan merupakan salah satu faktor pendukung (enabling/facilitating factors) untuk berperilaku. Pada penelitian ini, hal tersebut tidak terjadi karena kebijakan yang ada di sekolah biasanya merupakan kebijakan top down dari instansi diatasnya sehingga ada atau tidak adanya kebijakan terkait kesehatan reproduksi tidak berhubungan erat dengan bagaimana guru memberikan pendidikan kesehatan reproduksi remaja di sekolah tempat mereka bekerja, terlebih kebijakan seharusnya diikuti dengan sarana dan prasarana yang memadai. 
Berbeda dengan kebijakan, dua faktor pendukung yang lain yaitu sarana dan pelaksanaan memiliki hubungan yang signifikan dengan perilaku responden dalam pendidikan kesehatan reproduksi remaja. Temuan ini menguatkan model PrecedeProceed yang menyatakan bahwa ketersediaan dan akses terhadap sarana serta pelaksanaan berpotensi untuk mempengaruhi perilaku ${ }^{18}$. Sarana pembelajaran mempunyai kontribusi yang sangat besar terhadap perilaku guru dalam memberikan pendidikan kesehatan reproduksi remaja (nilai p: 0,000, OR: 110,5 , CI: $22,21-$ 549,52). Hal ini berarti responden yang memiliki sarana pembelajaran yang mendukung berpeluang 110,5 kali lebih tinggi untuk memberikan pendidikan kesehatan reproduksi yang sesuai dibandingkan dengan yang memiliki sarana yang tidak mendukung. Hasil penelitian ini sejalan dengan sebuah hasil penelitian yang menyatakan bahwa terdapat hubungan yang positif, kuat, dan signifikan antara fasilitas belajar dengan kualitas pembelajaran. Sarana pembelajaran merupakan hal penting untuk mendukung kualitas pembelajaran. $^{24}$ Metode pembelajaran yang dirancang guru untuk menyampaikan materi pelajaran tidak akan dapat terlaksana jika tidak didukung dengan sarana pembelajaran yang memadai. Untuk menyampaikan materi-materi kesehatan reproduksi, guru memerlukan dukungan sarana pembelajaran yang sesuai dan memadai. Misalnya ketika guru akan menyampaikan materi tentang sistem reproduksi manusia, selain adanya modul/bahan ajar, guru juga membutuhkan gambar, tayangan audiovisual dan juga phantom/model. Demikian juga ketika menyampaikan materi tentang NAPZA dan pengaruhnya terhadap kesehatan, para guru memerlukan alat bantu selain gambar juga audiovisual atau film cuplikan kasus korban NAPZA sehingga dapat memberikan contohcontoh nyata kepada siswa, bukan hanya dengan memberikan ceramah. Ketersediaan alat bantu juga akan memotivasi semangat para guru untuk menyampaikan materi-materi kesehatan reproduksi kepada siswanya. Pengadaan fasilitas belajar dalam upaya peningkatan kualitas pembelajaran sangat penting dan mutlak diperlukan, ini merupakan kewajiban sekolah untuk menyediakan fasilitas belajar yang memadai dan berkualitas sebagai upaya menumbuh-kembangkan dan peningkatan kualitas pembelajaran ke arah positif, karena pembentukan kualitas pembelajaran tidak lepas dari peran serta fasilitas belajar yang memadai.

Pada penelitian ini, responden yang menjabat sebagai kepala sekolah, wakil kepala sekolah bidang kurikulum dan wakil kepala sekolah bidang kesiswaan juga mengakui bahwa penyediaan alat bantu pembelajaran khususnya untuk topik-topik kesehatan reproduksi masih terbatas dan jauh dari ideal. Hal ini juga relevan dengan perilaku yang dilihat dari frekuensi melakukan evaluasi yang tidak sesuai dengan yang seharusnya. Padahal evaluasi proses pembelajaran merupakan hal yang sangat penting dilakukan untuk memperbaiki pembelajaran itu baik secara substansi, metode maupun media. Dari 421 (50,8\%) responden memiliki sarana pembelajaran yang kurang mendukung dalam pendidikan kesehatan reproduksi remaja. para responden mengatakan bahwa sarana pembelajaran yang kurang seperti alat bantu audio visual, LCD yang terbatas membuat metode pembelajaran yang digunakan juga menjadi terbatas. Padahal, pemenuhan kebutuhan sarana ini harusnya menjadi prioritas setiap sekolah sehingga tujuan pelaksanaan kesehatan reproduksi remaja di sekolah tercapai secara optimal.

Subvariabel pelaksanaan yang ditanyakan adalah kesesuaian latar belakang pendidikan dengan materi kesehatan reproduksi dan kecukupan jam mengajar untuk menyampaikan materi kesehatan reproduksi, 215 responden mengatakan tidak sesuai. Hal ini berarti lebih dari setengahnya $(51,1 \%)$ responden masih belum sesuai dalam pelaksanaan pendidikan kesehatan reproduksi remaja baik secara latar belakang pendidikan atau pun kecukupan mengajar atau pun kedua unsur pelaksanaan tersebut. Pelaksanaan pembelajaran mencakup alokasi waktu jam mengajar dan kesesuaian latar belakang pendidikan dengan relevansi mengajar topik kesehatan reproduksi yang melekat dalam mata pelajaran terkait pada penelitian ini memiliki hubungan yang signifikan dengan perilaku dalam pendidikan kesehatan reproduksi remaja (nilai p: 0,000, OR: 139,28, CI: 28,56- 679,30). Hal ini berarti pelaksanaan yang sesuai berpeluang 139 kali lebih tinggi untuk berperilaku yang sesuai dalam memberikan pendidikan kesehatan reproduksi remaja dibandingkan dengan pelaksanaan yang tidak sesuai. Hal ini sejalan 
dengan hasil penelitian lain yang menyatakan bahwa terdapat hubungan positif antara kualifikasi akademik dengan penguasaan kompetensi profesional pada guru. ${ }^{25}$

Penelitian ini memiliki keterbatasan yang mana data mengenai perilaku responden dalam pendidikan kesehatan reproduksi remaja yang meliputi kesesuaian jam mengajar dan ketercakupan materi didapatkan melalui wawancara, tidak dengan melakukan observasi langsung. Namun peneliti mengatasi hal ini dengan melihat jadwal pembelajaran dan catatan/laporan pembelajaran harian. Sehingga dengan demikian, dapat meminimalisir kemungkinan data yang disampaikan responden tidak sesuai dengan kenyataannya. Demikian pula untuk sarana pembelajaran dan kebijakan, selain didapatkan melalui wawancara kepada responden, peneliti juga melihat apa saja sarana pembelajaran yang tersedia dan dokumen kebijakan yang ada di sekolah.

Implikasi penelitian ini menguatkan teori yang dikemukakan oleh Green and Kreuter ${ }^{26}$, bahwa faktor sarana dan pelaksanaan yang termasuk dalam kategori enabling factors (faktor pendukung) memiliki hubungan yang sangat signifikan dengan perilaku guru dalam pendidikan kesehatan reproduksi remaja. hal ini berarti ketersediaan sarana pembelajaran kesehatan reproduksi yang diperlukan seperti gambar , bahan-bahan audiovisual, alat peraga, model, modul/buku ajar/bahan bacaan dan juga kemudahan akses untuk memberikan pembelajaran melalui fasilitas internet merupakan faktor pendukung yang sangat penting untuk guru dalam memberikan pendidikan kesehatan reproduksi. faktor pendukung lain yang sangat penting untuk diperhatikan adalah faktor pelaksanaan yaitu kesesuaian kualifikasi akademik dalam mengajarkan materi kesehatan reproduksi dan kecukupan jam yang dialokasikan untuk mengajarkan materi kesehatan reproduksi. artinya guru yang ditugaskan untuk mengajar topik kesehatan reproduksi pada mata pelajaran terkait hendaknya memiliki latar belakang pendidikan yang sesuai dan juga selalu mendapatkan update informasi terkait materi maupun metode pembelajaran kesehatan reproduksi melalui pelatihan-pelatihan kesehatan reproduksi remaja. selain itu juga jam pembelajaran untuk topik-topik kesehatan reproduksi hendaknya mencukupi sehingga guru dapat memberikan materi secara memadai.

\section{KESIMPULAN}

Sarana dan pelaksanaan merupakan dua subvariabel yang paling berhubungan dengan perilaku guru dalam memberikan pendidikan kesehatan reproduksi remaja. Variabel lain yang juga berhubungan adalah jenis kelamin, status kepegawaian, keikutsertaan pelatihan, pengetahuan dan sikap. Sedangkan sub-sub variabel karakteristik (usia, agama, tempat tinggal, pendidikan tertinggi, status guru, lama mengajar, lama menjabat), subvariabel waktu pelatihan, variabel identitas sekolah (lokasi dan status sekolah) dan subvariabel dukungan (kebijakan), tidak memiliki hubungan yang signifikan dengan perilaku guru dalam memberikan pendidikan kesehatan reproduksi remaja. Artinya, dari kelompok usia manapun, beragama apapun, bertempat tinggal satu kecamatan atau berbeda kecamatan dengan sekolah tempat bekerja, tingkat pendidikan tertinggi, status guru, lama mengajar, lama menjabat, waktu pelatihan di pre-service atau in-service, lokasi sekolah di pegunungan, perkotaan, dataran ataupun pantai, status sekolah negeri atau swasta, serta kebijakan mendukung atau tidak; apabila subvariabel sarana mendukung dan pelaksanaan sesuai, maka perilaku guru akan sesuai dalam memberikan pendidikan kesehatan reproduksi remaja yang dilihat dari ketercakupan materi dan kecukupan jam mengajar.

\section{SARAN}

Instansi terkait yaitu Dinas Pendidikan, Kementerian Agama dan sekolah hendaknya: 1) memberikan dukungan dalam pelaksanaan pendidikan kesehatan reproduksi remaja di sekolah melalui pemberian kesempatan pelatihan kesehatan reproduksi remaja kepada guru pengampu mata pelajaran maupun pengelola sekolah secara seimbang baik yang memiliki status kepegawaian PNS maupun non PNS, sehingga kualifikasi akademiknya terstandar sama, serta menugaskan guru mata pelajaran yang mengandung topik kesehatan reproduksi sesuai dengan kualifikasi akademik; 2) memberikan dukungan sarana pembelajaran seperti media-media pembelajaran kesehatan 
reproduksi remaja yang memadai supaya tujuan pembelajaran kesehatan reproduksi dapat tercapai secara optimal.

\section{UCAPAN TERIMA KASIH}

Penulis mengucapkan terima kasih kepada Kepala Dinas Pendidikan Provinsi Jawa Barat, Kepala Dinas Pendidikan Kabupaten Subang dan staf, Kepala Seksi Pendidikan Madrasah Perwakilan Agama Kabupaten Subang dan staf yang telah memberikan dukungan izin dan fasilitasi untuk kelancaran kegiatan pengumpulan data penelitian serta kepada Badan Penelitian dan Pengembangan Daerah Provinsi Jawa Barat yang telah memberikan dukungan dana untuk kegiatan penelitian ini.

\section{DAFTAR PUSTAKA}

1. World Health Organization. Promoting adolescent sexual and reproductive health through schools in low income countries: an information brief. 2009;

2. UNFPA and Center for reproductive rights. ICPD and Human Rights: 20 years advancing reproductive rights through $\mathrm{UN}$ treaty bodies and legal reform. 2013.

3. Adamchak, S., Bond, K., MacLaren, L., Magnani, R., Nelson, K., Seilzer J. A Guide to Monitoring and Evaluating Adolescent Reproductive Health Programs. Washington; 2000.

4. Statistics Indonesia, National Family Planning Coordinating Board, Ministry of Health of Indonesia, ICF International. Indonesia Demographic and Health Survey 2012: Adolescent Reproductive Health [Internet]. Jakarta: Statistics Indonesia; 2013. Available from: http://dhsprogram.com/pubs/pdf/FR275/F R275.pdf

5. McKay A. Sexual health education in the schools: Questions \& answers (3 rd edition). Sex Information and Education Council of Canada. 2005.

6. Kaushal P, Singh T, Padda AS, Deepti SS, Bansal P, Satija M, et al. Impact of health education on the knowledge, attitude and practices of teachers regarding reproductive health of adolescents of Amritsar, Punjab. J Clin Diagnostic Res. 2015;9(5):LC18-21.

7. Acharya N, Sabiha, Hariharan C, Gupta S, Athavale R. Study of change in knowledge and attitude of secondary school teachers toward adolescent reproductive health education after training program in rural schools of Wardha district, Maharashtra. J SAFOG. 2014;6(2):98-100.

8. Tanjung A, Utamadi G, Sahanaja J, Tafal Z. Kebutuhan Akan Informasi dan Pelayanan Kesehatan Reproduksi Remaja: Laporan Need Assesment di Kupang, Palembang, Singkawang, Cirebon dan Tasikmalaya. PKBI, UNFPA dan BKKBN; 2001.

9. Badan Pusat Statistik (BPS), Badan Kependudukan dan Keluarga Berencana Nasional (BKKBN), Kementerian Kesehatan. Indonesia Demographic and Health Survey: Adolescent Reproductive Health 2012. Jakarta, Indonesia: BPS, BKKBN, Kemenkes and ICF International; 2013.

10. Sulistyoningrum R. Hubungan antara Dukungan Sosial dan Akses Terhadap Informasi dengan Perilaku Sehat Reproduksi Remaja Slow Learner. J Promosi Kesehat [Internet]. 2011;1(1):24$34 . \quad$ Available from: http://www.journal.unair.ac.id/filerPDF/3h ubungan slow learner.pdf

11. Pusat Data dan Informasi Kementerian Kesehatan. Situasi Kesehatan Reproduksi Remaja. Jakarta: Kementerian Kesehatan; 2015.

12. Aktar, B., Sarker, M., Jenkins A. Exploring Adolescent Reproductive Health Knowledge, Perceptions, and Behavior, Among Students of Non-Government Secondary Schools Supported by BRAC Mentoring Program in Rural Bangladesh. J Asian Midwives. 2014;1(1):17-33.

13. Pawestri. Persepsi Guru SMA Kota Semarang Tentang Pendidikan Kesehatan Reproduksi Remaja. In: Journal of the Japanese Society of Pediatric Surgeons. 2011.

14. Badan Pusat Statistik Provinsi Jawa Barat. Provinsi Jawa Barat Dalam Angka 2018. 
BPS Provinsi Jawa Barat. Bandung; 2018.

15. Pusat Penelitian Pengembangan dan Informasi Badan Nasional Penempatan dan Perlindungan Tenaga Kerja Indonesia. Data Penempatan dan Perlindungan PMI. 2019.

16. Kementerian Pendidikan dan Kebudayaan RI. Jumlah Data Satuan Pendidikan (Sekolah) Per Kabupaten/Kota: Kab. Subang Berdasarkan Jenis SMP/MTs. 2019.

17. Scheaffer, Richard L.William Mendenhall, R.Lyman Ott, Gerow GK. Elementary Survey Sampling. Seventh ed. Julet M, editor. Boston: Richard Stratton; 2012. 452 p.

18. Howat,P., Brown,G., Bums,S., McManus A. Project Planning Using the PRECEDEproceed Model. In: Jirajwang, S., Liamputtong P, editor. Population Health, Communities and Health. Oxford University Press; 2009. p. 134-58.

19. Nastiti S. Perbedaan kinerja guru berdasarkan status kepegawaian pns dan non pns di sma negeri se-kabupaten rembang skripsi. 2016.

20. Vebriana C. Pengaruh Pendidikan dan Pelatihan, Pengalaman Mengajar dan Sikap Profesional Guru Terhadap Kompetensi Guru Ekonomi SMA Se-Kota Tegal.
Universitas Negeri Semarang; 2017.

21. Fitriana H, Siswantara P. Pendidikan Kesehatan Reproduksi Remaja Di SMPN 52 Surabaya. Indones J Public Heal. 2019;13(1):110.

22. Emilda R. Hubungan Tingkat Pemahaman Guru Tentang Kompetensi Pedagogik dengan Tingkat Kemampuan Mengajar Guru. Universitas Lampung; 2015.

23. Fuadi I. Hubungan Antara Pengetahuan dengan Sikap Masyarakat dalam Mencegah Leptospirosis di Desa Pabelan Kecamatan Kartasura Kabupaten Sukoharjo. Universitas Muhammadiyah Surakarta; 2016.

24. Budiono T. Hubungan Karakteristik Guru dan Fasilitas Belajar dengan Kualitas Pembelajaran Siswa di SMK Negeri 2 Yogyakarta. Universitas Negeri Yogyakarta; 2012.

25. Prasetyo B. Hubungan Kualifikasi Akademik dengan Penguasaan Kompetensi Profesional pada Guru Ilmu Pengetahuan Sosial (IPS) SMP/MTS Se-Kecamatan Kemangkon Kabupaten Purbalingga. 2015.

26. Porter CM. Revisiting Precede-Proceed: A leading model for ecological and ethical health promotion. Health Educ J. 2016;75(6):753-64. 